\title{
Seed Germination, Seedling Emergence, and Response to Herbicides of Triquetrous Murdannia (Murdannia triquetra) in Rice
}

\author{
Wei Tang, Jie Chen, Jianping Zhang, and Yongliang Lu*
}

\begin{abstract}
Triquetrous murdannia is an annual weed commonly found in rice fields in China. Laboratory and screenhouse experiments were carried out to determine the effect of light, temperature, osmotic and salt stress, seed burial depth, amount of rice residue, and depth of flooding on seed germination and seedling emergence of triquetrous murdannia and to evaluate the response of this weed to commonly available POST herbicides in China. Germination was greater than $93 \%$ under a wide day/night temperature range of $20 / 10$ to $30 / 20 \mathrm{C}$ in the light/dark regime. The time to onset of germination decreased as temperature increased. Germination was slightly stimulated when seeds were placed in light/dark conditions compared with seeds placed in the dark. The osmotic potential and $\mathrm{NaCl}$ concentration required for $50 \%$ inhibition of maximum germination were $-0.5 \mathrm{MPa}$ and $122 \mathrm{mM}$, respectively. The highest germination (68\%) was observed from seeds sown on the soil surface, but decreased with increasing burial depth. Only $7 \%$ of seedlings emerged from a depth of $4 \mathrm{~cm}$, and no seedlings emerged from seeds buried deeper than $6 \mathrm{~cm}$. Seedling emergence decreased from 93 to $35 \%$ with increasing quantity of rice residue (1 to $610^{3} \mathrm{~kg} \mathrm{ha}^{-9}$ ) applied on the soil surface. Seedling emergence was reduced by $40,48,64$, and $70 \%$ at flooding depths of 1,2 , 4, and $6 \mathrm{~cm}$, respectively, for the seeds sown on the soil surface. Fluroxypyr and MCPA herbicides provided $100 \%$ control of triquetrous murdannia at the 2- to 6-leaf stages; however, to achieve $100 \%$ control with bispyribac-sodium, MCPA + bentazone or MCPA + fluroxypyr, herbicides had to be applied by the 4-leaf stage. The results of this study could help in developing more sustainable and effective integrated weed management strategies for the control of triquetrous murdannia in rice fields in China. Nomenclature: Bispyribac-sodium; fluroxypyr; MCPA; MCPA + bentazone; MCPA + fluroxypyr; triquetrous murdannia, Murdannia triquetra (Wall.) Bruckn.; rice, Oryza sativa L.

Key words: Burial depth, flooding, osmotic stress, salt stress, rice residue.
\end{abstract}

Triquetrous murdannia is an annual weed and a member of the Commelinaceae family. This weed is widely distributed over east, central, and south China and is commonly found in ditch borders, floodplain wetlands, and farmlands, such as rice fields (Supplementary Figure 1). Generally, seedlings appear in late February, flowering occurs in mid-September, and seed dispersal begins in mid-October. Besides propagating by seeds, triquetrous murdannia can also develop new shoots by stem fragments buried in paddy or wet soil (Li 1998; Xu et al. 2014). Triquetrous murdannia can produce up to 1,000 seeds and 20 to 30 branches per plant. It is highly competitive with rice and hard to eradicate by manual control ( $\mathrm{Lu} \mathrm{1991).}$

Rice is one of the most important staple food crops in China, where it is grown under flooded conditions.

\footnotetext{
DOI: 10.1614/WS-D-16-00048.1

${ }^{*}$ First, third, and fourth authors: Associate Professor, Associate Professor, and Professor, State Key Laboratory of Rice Biology, China National Rice Research Institute, Hangzhou 311400, China; second author: Professor, School of Forestry and Biotechnology, Zhejiang A\&F University, Hangzhou 311300, China. Corresponding author's E-mail: luyongliang@caas.cn
}

As a result of looming water scarcity, shortage of labor, and increasing farming costs, farmers were disposed to shift from conventional flooded transplanting systems to systems involving labor- saving technologies, such as direct-seeded rice (DSR) and wheat-rice interplanting (Liu et al. 2014; Rao et al. 2007). Weed infestation is a serious problem in labor-saving systems because of simplified tillage and the absence of standing water, which would have a suppressive effect on weed growth during rice emergence and provide a seedling size advantage for rice seedlings (Chauhan 2012; Opeña et al. 2014). Changes in the establishment method of transplanted rice to DSR have led to shifts in weed flora (Ahmed et al. 2014; Chauhan and Johnson 2010; Singh et al. 2009). Triquetrous murdannia has become a dominant species in the weed community in DSR and/or wheat-rice rotated fields in China (Bao 2003; He et al. 1999; Tian et al. 2015; Wang et al. 2013).

Cultural practices such as crop rotation or adequate tillage can help to manage weeds; however, it has been the practice of many farmers to use herbicides as the most economic and effective weed management option in rice fields

Tang et al.: Germination of triquetrous murdannia • 
(Mahajan and Chauhan 2013; Suria et al. 2011). Usually, triquetrous murdannia emerges by April, which is before the planting of single-cropping rice or late double-cropping rice in central and south China, thus escaping the efficacy of PRE herbicides (Supplementary Figure 2). Therefore, it is critical to control this weed species by using POST herbicides. Previous studies have reported that early POST applications of pyribenzoxim, fluroxypyr, bispyribacsodium, and MCPA were particularly effective in controlling triquetrous murdannia in rice fields (He et al. 1999; Tan 2014; Tian et al. 2015). However, the efficacy of POST herbicides is dependent on the growth stage of the targeted weed. Herbicide efficacy is reduced when applied on older plants (Opeña et al. 2014; Singh and Singh 2004). Response of triquetrous murdannia at different growth stages to POST herbicides is not available in the literature.

Successful establishment of a weed species depends heavily on its ability to germinate and emerge under a wide range of environmental conditions. Seed germination and seedling emergence are usually influenced, directly or indirectly, by many environmental factors, such as temperature, light, soil $\mathrm{pH}$, moisture and salinity stress, seed burial depth, and amount of crop residue in the field (Chachalis and Reddy 2000; Chauhan 2012; Koger et al. 2004). The development of effective integrated weed management strategies depends on a detailed knowledge of weed seed biology. Wang et al. (2013) and Tian et al. (2015) studied the occurrence characteristics of triquetrous murdannia in rice fields. The seed germination and emergence behavior were affected by various environmental factors that may determine the presence of triquetrous murdannia in the field. To date, detailed study of the germination and emergence biology of triquetrous murdannia has not been reported.

Therefore, the objectives of this study were: (1) to determine the effects of temperature, light, osmotic and salt stress, burial depth, flooding depth, and amount of rice residue on triquetrous murdannia germination and emergence; and (2) to evaluate the efficacy of commonly available POST herbicides on different growth stages of triquetrous murdannia.

\section{Material and Methods}

Experiments were conducted at the laboratory and screenhouse (an 8 by $20 \mathrm{~m}$ chamber framed with $1 \mathrm{~cm}$ iron mesh and covered overhead with a transparent plastic cover to prevent rain damage) of the China National Rice Research Institute (CNRRI), Hangzhou, China $\left(30.04^{\circ} \mathrm{N}, 119.55^{\circ} \mathrm{E}\right)$, from February to June 2015. Seeds of mature triquetrous murdannia were collected in October 2014 from the upland rice fields at CNRRI. After collection, seeds were cleaned, dried in the shade, and stored in paper bags at room temperature until being used in the experiments. All experiments were conducted in a randomized complete block design with four replications. Each replication was considered a block and was arranged on a different shelf in the incubator or bench in the screenhouse. Each experiment was conducted twice.

General Germination Test. Seed germination of triquetrous murdannia was determined by placing 25 seeds in 9-cm-diameter petri dishes containing two layers of Whatman No.1 filter paper and $5 \mathrm{ml}$ of distilled water or a treatment solution. Petri dishes were sealed with Parafilm (American National Can, Greenwich, CT) to reduce loss of water and were placed in an incubator (RTOP-310D; Zhejiang Top Instrument, Hangzhou, China) at fluctuating day/night temperatures of $25 / 15 \mathrm{C}$. Photoperiod was set at $12 \mathrm{~h}$ to coincide with the high-temperature period. These conditions were found optimum in the temperature and light experiments. The visible protrusion of the radicle was the criterion for germination (Chauhan and Johnson 2008c). Germination values were calculated as the total number of seeds germinated divided by the total number of seeds in the petri dish.

Effect of Temperature and Light on Germination. The objective of this study was to find the optimum temperature and light regime for seed germination of triquetrous murdannia. Germination was determined by incubating seeds under fluctuating day/night temperatures $(35 / 25,30 / 20$, $25 / 15$, and 20/10 C) in both light/dark and dark regimes. For the dark treatment, the petri dishes were wrapped in three layers of aluminum foil to prevent any light penetration. Four incubators (RTOP-310D) were used in the test, and each temperature regime was conducted in a separate incubator. The number of germinated seeds in the light/dark regime was counted daily for up to $15 \mathrm{~d}$, whereas in the dark regime, the germination was recorded only after $15 \mathrm{~d}$. Seeds that failed to germinate in the dark after $15 \mathrm{~d}$ were moved to the light/ dark regime with $5 \mathrm{ml}$ of distilled water added for another $15 \mathrm{~d}$ period, at the end of which the germinated seeds were counted. 
Effect of Osmotic and Salt Stress on Germination. The effect of water stress on triquetrous murdannia seed germination was studied by placing 25 seeds in $5 \mathrm{ml}$ solutions with osmotic potentials of $0,-0.1,-0.2,-0.4,-0.6$, or $-0.8 \mathrm{MPa}$. The solution concentrations were prepared by dissolving $0,99.4,140.6,198.8,243.4$, and $281 \mathrm{~g}$ of polyethylene glycol 8000 (Sigma-Aldrich, St. Louis, MO) in $1 \mathrm{~L}$ of distilled water (Michel 1983; Opeña et al. 2014). The effect of salt stress on germination of triquetrous murdannia was determined by placing 25 seeds in petri dishes containing $5 \mathrm{ml}$ solutions of 0,25 , $50,100,150,200$, and $250 \mathrm{mM} \mathrm{NaCl}$. The solutions were prepared by dissolving $0,1.5,2.4,5.8,8.8,11.7$, and $14.6 \mathrm{~g}$ of $\mathrm{NaCl}$ per $1 \mathrm{~L}$ of distilled water. The petri dishes were incubated under fluctuating day/night temperatures of $25 / 15 \mathrm{C}$ with a $12 \mathrm{~h}$ photoperiod condition to test germination. The number of germinated seeds was counted $15 \mathrm{~d}$ after sowing.

\section{Effect of Burial Depth on Seedling} Emergence. The effect of burial depth on seedling emergence was determined in a pot experiment conducted in a screenhouse. The soil used in all pot experiments was collected from upland rice fields at CNRRI with a $\mathrm{pH}$ of 6.0 and consisted of $40 \%$ sand, $32 \%$ silt, and $28 \%$ clay. The soil was autoclaved and passed through a $3 \mathrm{~mm}$ sieve. Twenty-five seeds were sown at depths of $0,0.5,1$, 2,4 , and $6 \mathrm{~cm}$ below the soil surface in plastic pots (12 cm diameter, $10 \mathrm{~cm}$ height) that had drainage holes at the bottom. In order to prevent soil from leaking out, a piece of filter paper was placed inside at the bottom of each pot. Pots were initially irrigated with an overhead sprinkler and were later subirrigated. In all pot experiments, visible coleoptiles on the soil surface indicated emergence. The number of seeds that emerged was counted $20 \mathrm{~d}$ after planting.

\section{Effect of Rice Residue Amount on Seedling} Emergence. This study was conducted in the same screenhouse as described in the previous experiment. Twenty-five seeds were sown on the soil surface in plastic pots containing finely chopped rice straw (stems and leaves) at rates equivalent to $0,1,2,4$, and $610^{3} \mathrm{~kg} \mathrm{ha}^{-1}$. The amounts of rice straw used in this study reflect the amount of straw produced in single-cropping rice fields (Wei et al. 2012). The condition of the soil, the pots used, and emergence counting in this experiment were done as described above for the seed burial depth experiment.
Effect of Flooding Depth on Seedling Emergence. Twenty-five seeds were sown on the soil surface in small plastic pots $(9 \mathrm{~cm}$ diameter, $8 \mathrm{~cm}$ height) containing the same soil described in the previous screenhouse experiments. The pots containing the seeds were placed inside larger plastic pots $(12 \mathrm{~cm}$ diameter, $10 \mathrm{~cm}$ height $)$ to retain water and maintain flooding depths of $0,1,2,4$, and $6 \mathrm{~cm}$. After seeding, the pots were kept at saturated conditions for $5 \mathrm{~h}$ to let the seeds absorb water and to prevent them from floating. Flooding to the desired depth was introduced $5 \mathrm{~h}$ after seeding, and pots were kept flooded at the aforementioned depths for $20 \mathrm{~d}$. The number of emerged seedlings was counted after $20 \mathrm{~d}$ of flooding.

Effect of POST Herbicides on Seedling Survival and Growth. Twelve seeds were sown on the soil surface in pots $(9 \mathrm{~cm}$ diameter, $8 \mathrm{~cm}$ height $)$ and covered with a thin layer of sterilized soil. Seedlings were thinned to six plants per pot at $7 \mathrm{~d}$ after sowing. Ten POST herbicides labeled for use in rice fields for annual broadleaf and non-grass monocot weed control were selected (Table 1). Herbicides were sprayed at the 2-, 4-, and 6-leaf stages using a laboratory spray tower (3WPSH-700E; Nanjing Institute of Agricultural Mechanization Ministry of Agriculture, Nanjing, China) equipped with a flat-fan nozzle (Teejet 80015) to deliver $300 \mathrm{~L} \mathrm{ha}^{-1}$ at $230 \mathrm{kPa}$. The POST herbicides used included bensulfuron-methyl (10\% WP; Jiangsu Jiangnan Agrochemical, Changzhou, China) at $375 \mathrm{~g}$ ai ha ${ }^{-1}$; bentazone ( $48 \%$ SL; BASF, Shanghai, China) at $1200 \mathrm{~g}^{\text {ai ha }}{ }^{-1}$; bispyribac-sodium (10\% SC; Kumiai Chemical Industry, Nanjing, China) at $27 \mathrm{~g}$ ai $\mathrm{ha}^{-1}$; ethoxysulfuron (15\% WDG; Jiangsu Jiangnan Agrochemical, Changzhou, China) at $21 \mathrm{~g}$ ai $\mathrm{ha}^{-\mathrm{P}}$; fluroxypyr (20\% EC; Dow Agro Sciences, Nanjing, China) at $338 \mathrm{~g}$ ai ha ${ }^{-1}$; MCPA (56\% SP; Shandong Qiaochang Chemical, Binzhou City, China) at $506 \mathrm{~g}$ ai ha ${ }^{-1}$; pyrazosulfuron $(10 \%$ WP; Nissan Chemical Industries, Tianjin, China) at $23 \mathrm{~g}_{\text {ai ha }}{ }^{-1}$; MCPA + bentazone (20\% AS; Mefront Agricultural Chemicals, Wenzhou, China) at $540 \mathrm{~g}$ ai $\mathrm{ha}^{-1}$; MCPA + fluroxypyr (42.5\% EC; Lier Chemical, Mianyang, China) at $248 \mathrm{~g} \mathrm{ha}^{-1}$; pyrazosulfuron + mefenacet $\quad(75 \%$ WP; Mefront Agricultural Chemicals) at $563 \mathrm{~g} \mathrm{ai} \mathrm{ha}^{-1}$. There was a nontreated control for each leaf stage. The number of seedlings that survived (with green stem or with green leaves on the plant) was counted $21 \mathrm{~d}$ after herbicide application. The shoots (leaf and stem) of the plants were cut from the base of the soil, cleaned, bagged, and dried in an oven at $70 \mathrm{C}$ for $72 \mathrm{~h}$ to obtain dry biomass. 
Table 1. Effect of POST herbicides on survival (\%) and shoot biomass ( $\mathrm{g} \mathrm{pot}^{-1}$ ) of triquetrous murdannia when sprayed at 2-, 4-, and 6-leaf stages of the weed.

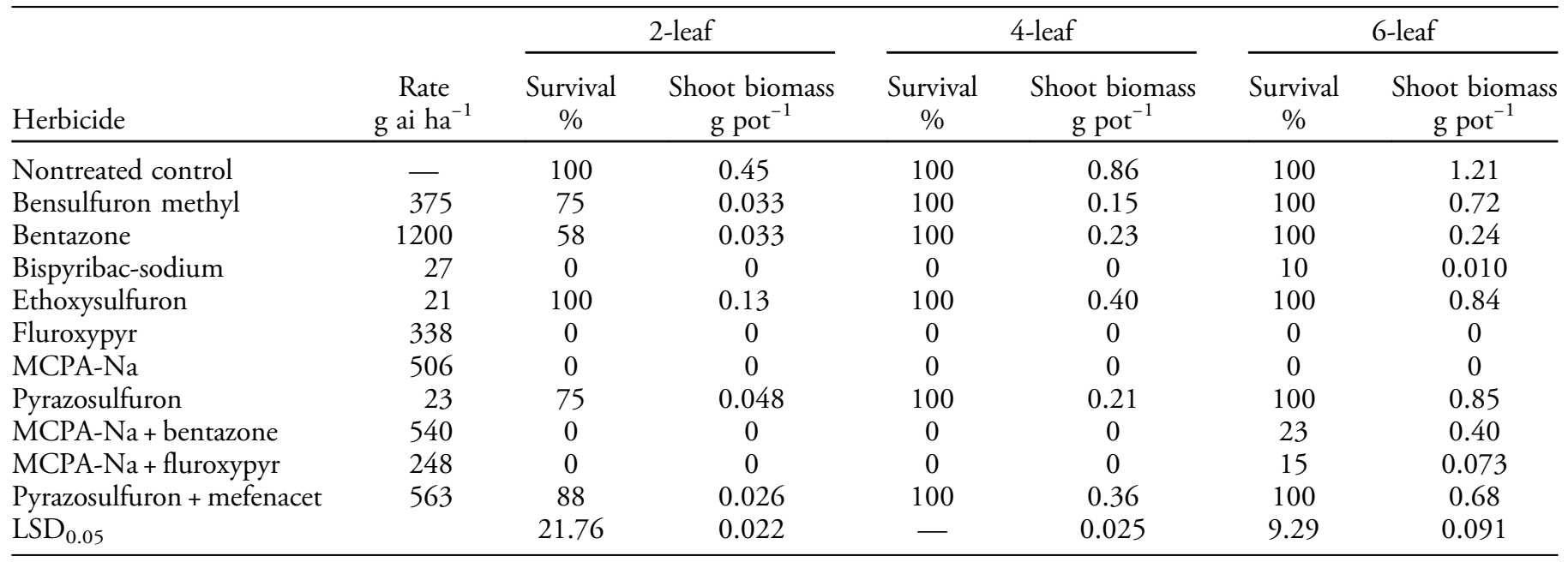

Statistical Analyses. The data of the repeat experiments were pooled, because no experiment by treatment interaction was revealed. All data met normality conditions. Data obtained from rice residue and herbicide treatment experiments were subjected to analysis of variance with the use of SPSS software, version 13.0 (SPSS, Chicago, IL). Mean comparison was performed using Fisher's protected least significant difference test, where the overall differences were significant $(\mathrm{P} \leq 0.05)$. Data were analyzed using regression analysis to determine relationships among different temperature regimes, salt and osmotic concentrations, burial depths, residue amounts, and flooding depths. These were best fit to a functional three-parameter sigmoid model using Origin, version 8.0 (OriginLab, Northampton, MA). The model (Ahmed et al. 2015) fit to the fluctuating temperatures was:

$$
G=G_{\max } /\left\{1+\exp \left[-\left(T-T_{50}\right) / G_{\text {rate }}\right]\right\}
$$

where $G$ is the total germination (\%) at time $T, G_{\max }$ is the maximum germination (\%), $T_{50}$ is the time required for $50 \%$ of maximum germination, and $G_{\text {rate }}$ indicates the slope. The model fit to varying osmotic and salt concentrations was:

$$
G=G_{\max } /\left\{1+\exp \left[-\left(x-x_{50}\right) / G_{\text {rate }}\right]\right\}
$$

where $G$ is the total germination (\%) at osmotic potential or salt concentration $x, G_{\max }$ is the maximum germination (\%), $x_{50}$ is the osmotic potential or salt concentration required for $50 \%$ inhibition of maximum germination, and $G_{\text {rate }}$ indicates the slope. An OriginPro exponential decay model in the form of:

$$
E=A \exp (-x / t)+E_{0}
$$

was fit to seedling emergence (\%) obtained at different burial and flooding depths, where $E$ represents cumulative emergence (\%) at depth $x, E_{0}$ is the offset, $A$ is the amplitude, and $t$ is the decay constant.

\section{Results and Discussion}

Effect of Temperature and Light. Germination of triquetrous murdannia seeds was influenced by the combined effect of light and temperature $(\mathrm{P}<0.05)$; germination in continuous darkness was significantly lower than seeds in light/dark in all the tested temperature regimes (Figure 1). In the continuousdark conditions, seed germination was lower at $35 / 25 \mathrm{C}(46 \%)$ than at 30/20, 25/10, and 20/10 C (55 to $61 \%)$. Also, when triquetrous murdannia seeds were exposed to the light/dark conditions, higher cumulative germination was observed at $30 /$ $20,25 / 15$, and $20 / 10 \mathrm{C}$ than at the $35 / 25 \mathrm{C}$ temperature regimes with 94,96 , and $96 \%$ versus $78 \%$, respectively.

Seeds of triquetrous murdannia exposed to light/ dark conditions at the lowest temperature regime took longer time to reach $50 \%$ germination (Figure 2). The time it took for $50 \%$ germination (of the maximum germination) at 20/10, 25/15, 30/ 20 , and $35 / 25 \mathrm{C}$ was $8,5,3$, and $2 \mathrm{~d}$, respectively.

144 • Weed Science 65, January-February 2017 


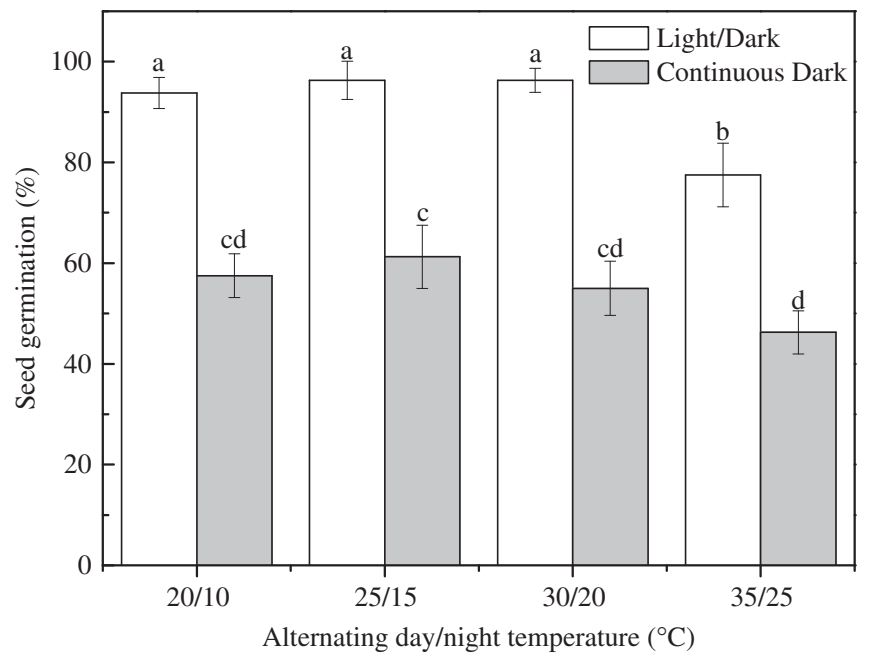

Figure 1. Cumulative germination of triquetrous murdannia incubated at alternating day/night temperatures (20/10, 25/15, $30 / 20$, and 35/25 C) and light (light/dark and dark). Vertical bars represent standard errors of the mean. Bars designated by different lowercase letters are significantly different according to Fisher's protected LSD at $\mathrm{P} \leq 0.05$.

However, as mentioned earlier, cumulative germination (\%) at $15 \mathrm{~d}$ was similar for $30 / 20,25 / 15$, and 20/10 C temperature regimes.

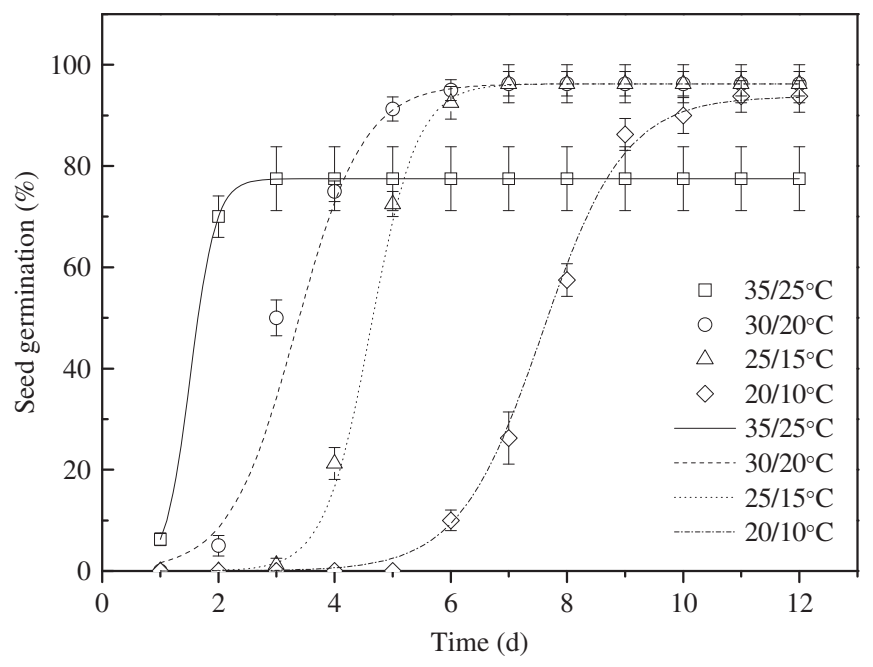

$35 / 25{ }^{\circ} \mathrm{C} \mathrm{G} \%=77.5 /(1+\exp (-4.7 *(\mathrm{~T}-1.5))) \mathrm{R}^{2}=0.99$ $30 / 20{ }^{\circ} \mathrm{C} \mathrm{G} \%=96.3 /(1+\exp (-1.7 *(\mathrm{~T}-3.3))) \mathrm{R}^{2}=0.99$ $25 / 15{ }^{\circ} \mathrm{C} \mathrm{G} \%=96.3 /(1+\exp (-2.5 *(\mathrm{~T}-4.6))) \mathrm{R}^{2}=0.99$ $20 / 10{ }^{\circ} \mathrm{C} \mathrm{G} \%=93.8 /(1+\exp (-1.4 *(\mathrm{~T}-7.6))) \mathrm{R}^{2}=0.99$

Figure 2. Effect of alternating day/night temperatures (20/10, $25 / 15,30 / 20$, and $35 / 25 \mathrm{C}$ ) and light (light/dark) on germination of triquetrous murdannia seeds over a $12 \mathrm{~h}$ photoperiod for $15 \mathrm{~d}$. Vertical bars represent standard errors. The line represents a threeparameter sigmoid model, $G=G_{\max } /\left\{1+\exp \left[-\left(T-T_{50}\right) / G_{\text {rate }}\right]\right\}$, fit to the data, where $G$ is the total germination (\%) at time $T$, $G_{\max }$ is the maximum germination (\%), $T_{50}$ is the time required for $50 \%$ of maximum germination, and $G_{\text {rate }}$ indicates the slope at $T=T_{50}$.
Temperature is considered an important factor affecting germination of several weed species. In a similar study, germination in doveweed [Murdannia nudiflora (L.) Brenan] was significantly greater at $35 / 25 \mathrm{C}$ than it was at 30/20 C (Ahmed et al. 2015). The ability of triquetrous murdannia to germinate at all temperatures suggests that this species could emerge throughout the year at low altitudes in warm areas of China.

Varied germination responses to light have been reported among different weed species. Previous studies found that some weed species, such as texasweed [Caperonia palustris (L.) St. Hil.] (Koger et al. 2004), American sloughgrass [Beckmannia syzigachne (Steud.) Fernald] (Rao et al. 2008), and rose natalgrass [Melinis repens (Willd.) Zizka] (Stokes et al. 2011) have no light requirement for germination. In contrast, weed species such as common ragweed (Ambrosia artemisiffolia L.) (Baskin and Baskin 1980), common lambsquarters (Chenopodium album L.) (Bouwmeester and Karssen 1993), and eclipta [Eclipta prostrata (L.) L.] (Chauhan and Johnson 2008b) require light for germination.

The current study supports the findings of Chauhan and Johnson (2008c, 2008b) and Opeña et al. (2014) that temperature and light are important factors influencing weed seed germination. In a previous study, Chauhan and Johnson (2008b) found that eclipta germination at $30 / 20 \mathrm{C}$ under light/dark conditions was significantly higher than at 25/15 and 35/25 C temperature regimes. Germination of goosegrass [Eleusine indica (L.) Gaertn.] (Chauhan and Johnson 2008c) and Echinochloa glabrescens (Munro ex Hook.) (Opeña et al. 2014) was significantly higher in light/dark conditions than in dark conditions. In our study, seeds could germinate in the dark, which indicates that light is not a prerequisite for germination of triquetrous murdannia. Such results also imply that seeds of this weed species are not photoblastic and may germinate even when buried at shallow depths in the soil and after canopy closure in rice and other crops. Germination of triquetrous murdannia stimulated by light suggests that this species could be a problematic weed in no-till systems, wherein much of the weed seedbank remains on the soil surface (Chauhan and Johnson 2009).

In our study, when nongerminated seeds from the dark treatment were transferred to light/dark conditions at 30/20 C, their germination reached over $90 \%$ (unpublished data). These results indicate that the exposure of previously buried triquetrous murdannia seeds to light may trigger germination in field conditions. 
Effect of Osmotic Stress on Germination. Seed germination of triquetrous murdannia was strongly influenced $(\mathrm{P}<0.05)$ by water potential (Figure 3$)$. Germination decreased from 96 to $21 \%$ as osmotic potential decreased from 0 to $-0.6 \mathrm{MPa}$ and was completely inhibited at $\geq-0.8 \mathrm{MPa}$. The osmotic potential required to inhibit $50 \%$ germination was $-0.5 \mathrm{MPa}$. Similar results were reported for doveweed and redroot pigweed (Amaranthus retroflexus L.), in which $-0.40 \mathrm{MPa}$ reduced seed germination by $50 \%$ for both weed species (Ahmed et al. 2015; Ghorbani et al. 1999). These results indicate that the seeds of triquetrous murdannia were not adversely affected by exposure to low osmotic potentials for up to $15 \mathrm{~d}$. They also suggest that most of the seeds will germinate in moist conditions, while seeds maintained under dry conditions may wait until adequate moisture conditions occur before germinating.

Effect of Salt Stress on Germination. Maximum germination of 96 and $95 \%$ was observed in seeds incubated at 0 and $25 \mathrm{mM} \mathrm{NaCl}$ concentration, respectively, and no germination was observed at $\geq 200 \mathrm{mM}$ (Figure 4). Germination was greater than $75 \%$ at $100 \mathrm{mM}$ and decreased to $18 \%$ at $150 \mathrm{mM}$. The salt concentration required for $50 \%$ reduction in germination was $122 \mathrm{mM}$.

Seed germination response to salt stress differs according to weed species. The $\mathrm{NaCl}$ concentration

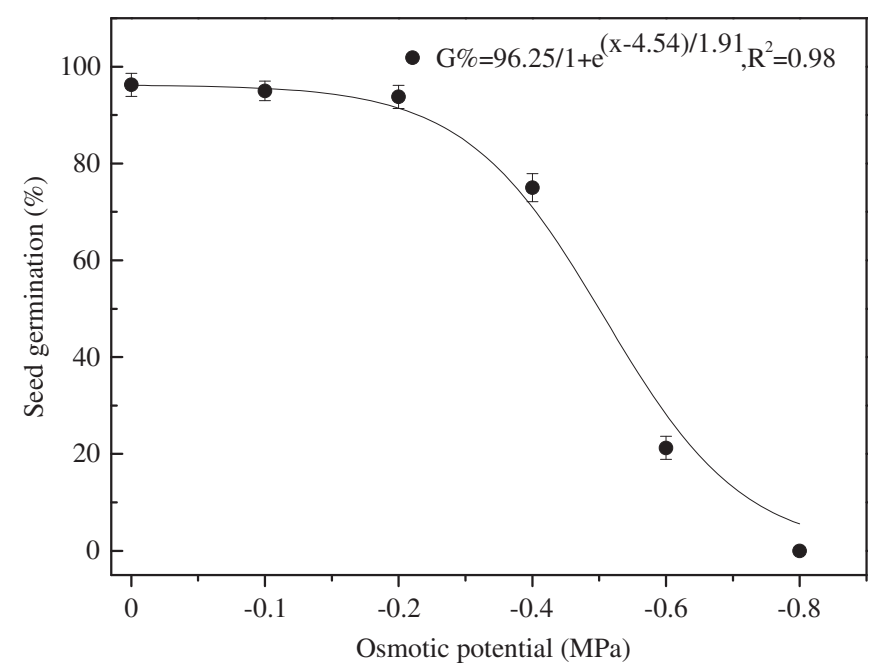

Figure 3. Effect of osmotic potential on germination of triquetrous murdannia seeds incubated at $25 / 15 \mathrm{C}$ with a $12 \mathrm{~h}$ photoperiod for $15 \mathrm{~d}$. Vertical bars represent standard errors. The line represents a three-parameter sigmoid model, $G=G_{\max } /$ $\left\{1+\exp \left[-\left(x-x_{50}\right) / G_{\text {rate }}\right]\right\}$, fit to the data, where $G$ is the total germination $(\%)$ at osmotic potential $x, G_{\max }$ is the maximum germination (\%), $x_{50}$ is the osmotic potential required for $50 \%$ inhibition of maximum germination, and $G_{\text {rate }}$ indicates the slope at $x=x_{50}$. for $50 \%$ reduction in germination for giant false sensitive plant (Mimosa diplotricha C. Wright) and Japanese brome (Bromus japonicas Thunb.) was 255 and $202 \mathrm{mM} \mathrm{NaCl}$, respectively (Chauhan and Johnson 2008a; Li et al. 2015). The concentration for $50 \%$ germination reduction for Ceratocarpus arenarius (L.) was $400 \mathrm{mM} \mathrm{NaCl}$ (Ebrahimi and Eslami 2012). On the other hand, some weed seeds, such as texasweed and goosegrass were found to be sensitive to high $\mathrm{NaCl}$ concentrations (Chauhan and Johnson 2008b; Koger et al. 2004). Our results suggest that triquetrous murdannia has the ability to germinate under moderate soil salinity, and this species might not be a problematic weed in high-saline soils.

Effect of Seed Burial Depth on Seedling Emergence. Seedling emergence of triquetrous murdannia was significantly affected by seed burial depth (Figure 5). Cumulative seedling emergence declined with increasing burial depth. Highest seedling emergence $(68 \%)$ was observed when seeds were sown on the soil surface, and only $2 \%$ emergence occurred when the seeds were sown at $4 \mathrm{~cm}$ depth. No emergence occurred when seeds were sown at $\geq 6 \mathrm{~cm}$ depth. It has been reported for many weed species that seedling emergence decreased with increasing burial depth (Bello et al. 2000; Fandrich and Mallory-Smith 2006; Rao et al. 2008). Seedling

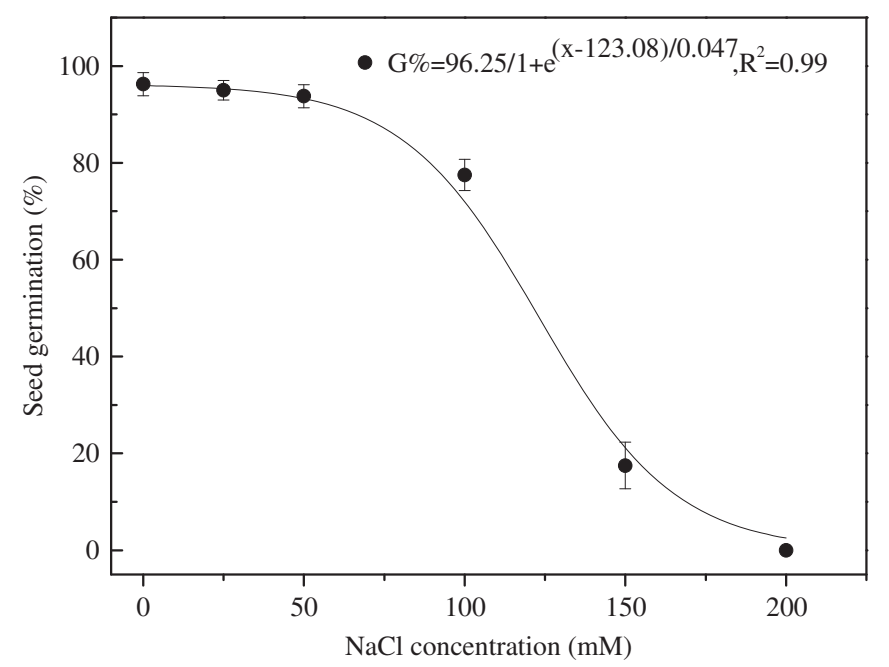

Figure 4. Effect of $\mathrm{NaCl}$ concentration on germination of triquetrous murdannia seeds incubated at $25 / 15 \mathrm{C}$ with a $12 \mathrm{~h}$ photoperiod for $15 \mathrm{~d}$. Vertical bars represent standard errors. The line represents a three-parameter sigmoid model, $G=G_{\max } /$ $\left\{1+\exp \left[-\left(x-x_{50}\right) / G_{\text {rate }}\right]\right\}$, fit to the data, where $G$ is the total germination (\%) at $\mathrm{NaCl}$ concentration $x, G_{\max }$ is the maximum germination (\%), $x_{50}$ is the $\mathrm{NaCl}$ concentration required for $50 \%$ inhibition of maximum germination, and $G_{\text {rate }}$ indicates the slope at $x=x_{50}$. 


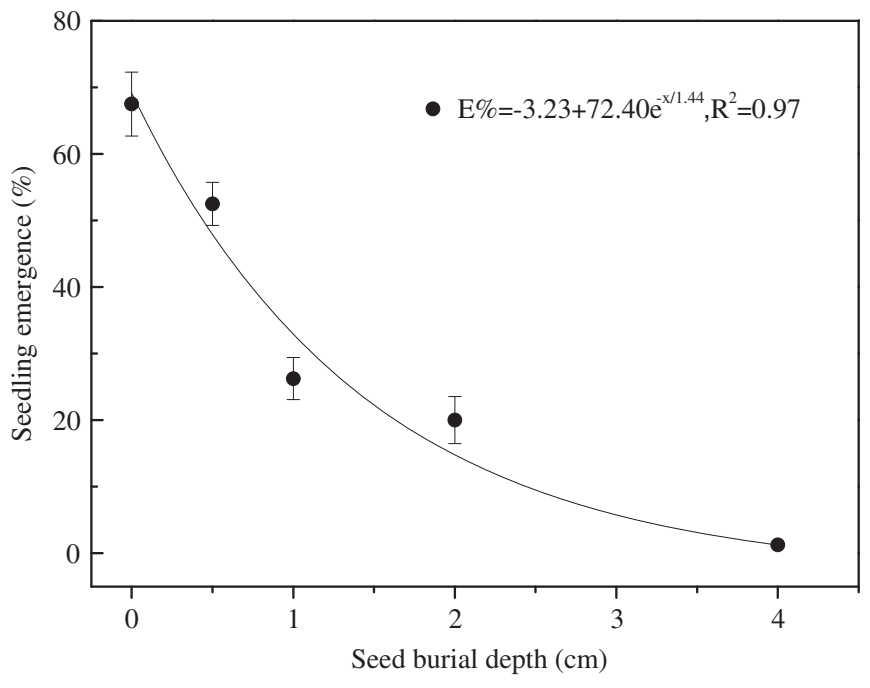

Figure 5. Effect of seed burial depth on emergence of triquetrous murdannia seedlings in the screenhouse ( $20 \mathrm{~d}$ after sowing). Vertical bars represent standard errors. The line represents an exponential decay model, $E=A \exp (-x / t)+E_{0}$, where $E$ represents cumulative emergence (\%) at seed burial depth $x, E_{0}$ is the offset, $A$ is the amplitude, and $t$ is the decay constant.

emergence from deep in the soil is usually inhibited by the absence of light, limitation on soil gas diffusion, and inadequate nutritional content of weed seeds to support emergence (Benvenuti and Macchia 1995; Bewley and Black 1994).

Similar to triquetrous murdannia, weed species such as horseweed [Conyza canadensis (L.) Cronq.] (Nandula et al. 2006), Echinochloa glabrescens (Opeña et al. 2014), and romerillo [Bidens alba (L.) DC.] (Ramirez et al. 2012) had their highest emergence rates when seeds were sown on the soil surface. Greater emergence on the soil surface in triquetrous murdannia is consistent with stimulation of germination by light. These results also suggest that no-till or strip-till DSR systems may favor its emergence in the field. When seeds are buried deeper than $2 \mathrm{~cm}$, establishment of this weed might be more difficult, as the emergence was lower. Thus, plowing seeds to a depth below $4 \mathrm{~cm}$ through adequate tillage operations might be useful for managing triquetrous murdannia.

Effect of Rice Residue Amount on Seedling Emergence. Triquetrous murdannia seedling emergence was significantly affected by the amount of rice residue. The addition of residue at 1 to $210^{3} \mathrm{~kg} \mathrm{ha}^{-1}$ increased the emergence of seedlings (Figure 6). Maximum seedling emergence (93\%) was observed when $110^{3} \mathrm{~kg} \mathrm{ha}^{-1}$ residue was applied, which was significantly $(\mathrm{P}<0.05)$ different from all other treatments. Cumulative seedling emergence across different

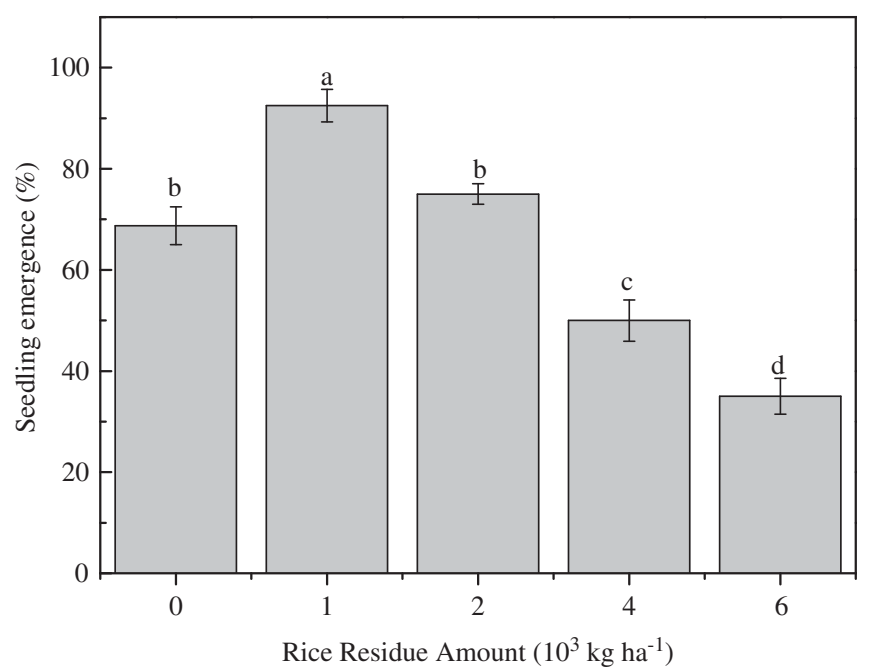

Figure 6. Effect of rice residue amount on emergence of triquetrous murdannia seedlings in the screenhouse $(20 \mathrm{~d}$ after sowing). Vertical bars represent standard errors of the mean. Bars designated by different lowercase letters are significantly different according to Fisher's protected LSD at $\mathrm{P} \leq 0.05$.

amounts of residue ( 1 to $\left.610^{3} \mathrm{~kg} \mathrm{ha}^{-1}\right)$ decreased from 93 to $35 \%$.

Reduced seedling emergence and biomass with the addition of crop residue has been reported for many weed species. For example, doveweed and barnyard grass [Echinochloa crus-galli (L.) P. Beauv] were reported to have a marked reduction in seedling emergence and biomass with increased amount of rice residue (Ahmed et al. 2015; Chauhan and Johnson 2011). This was probably due to the reduction in light transmittance, lower soil temperatures, and physical obstruction by use of rice residue as mulch to inhibit weed seed germination (Crutchfield et al. 1985; Teasdale and Mohler 1993). In this study, increased seed germination with the addition of 1 to $210^{3} \mathrm{~kg} \mathrm{ha}^{-1}$ rice residues compared with the absence of residue could be a result of higher availability of soil moisture due to better soil seed contact. Our results also suggest that the addition of rice residue up to $610^{3} \mathrm{~kg} \mathrm{ha}^{-1}$ may help in suppressing triquetrous murdannia seedling emergence in fields. However, these high amounts of rice residue may not be feasible in China, as the common practice of most famers is to burn or carry away the straw after harvest.

\section{Effect of Flooding Depth on Seedling} Emergence. When the seeds were sown on the soil surface, there was a marked reduction in seedling emergence of triquetrous murdannia with increasing flooding depth (Figure 7). Seedling emergence was reduced by $40,48,64$, and $70 \%$ at flooding depths

Tang et al.: Germination of triquetrous murdannia • 147 


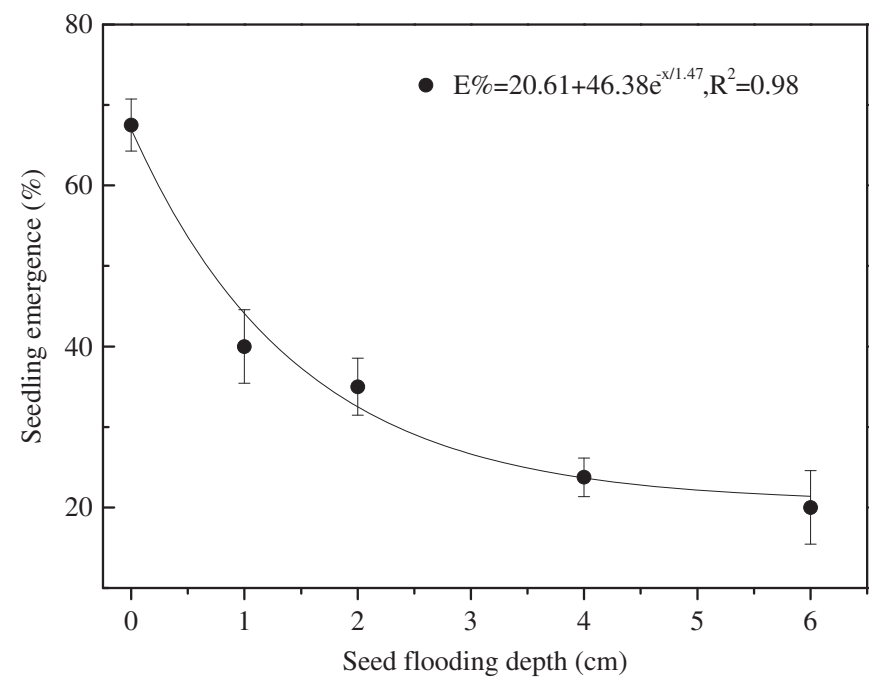

Figure 7. Effect of flooding depth on emergence of triquetrous murdannia seedlings in the screenhouse ( $20 \mathrm{~d}$ after sowing). Vertical bars represent standard errors. The line represents an exponential decay model, $E=A \exp (-x / t)+E_{0}$, where $E$ represents cumulative emergence (\%) at seed flooding depth $x, E_{0}$ is the offset, $A$ is the amplitude, and $t$ is the decay constant.

of $1,2,4$, and $6 \mathrm{~cm}$, respectively. Reduction in emergence of weeds under flooded conditions may be a result of several factors, including reduced $\mathrm{O}_{2}$ levels, accumulation of $\mathrm{CO}_{2}$, and the presence of reduced forms of chemical radicals and toxic gaseous products of anaerobic decomposition, such as methane, nitrogen, nitrous oxides, and sulfides (Smith and Fox 1973).

Similar to triquetrous murdannia, emergence of many weed species, such as rice flatsedge (Cyperus iria L.), junglerice [Echinochloa colona (L.) Link], and fimbry [Fimbristylis miliacea (L.) Vahl], were reduced greatly with increasing flooding depth (Civico and Moody 1979; Smith and Fox 1973). Our results indicate that shallow flooding can be used to suppress the emergence of triquetrous murdannia. In some areas of eastern and central China, farmers practice a double-cropping system in which rice is planted in June following the wheat harvest. At that time, triquetrous murdannia had already germinated and grown in nonirrigated soil for over $1 \mathrm{mo}$. To reduce the dispersal of triquetrous murdannia stem fragments in flooded rice fields (Supplementary Figure 3), fields used in double-cropping systems must undergo pretreatment with a broad-spectrum herbicide before rice is planted to manage this weed.

\section{Effect of POST Herbicides on Seedling Survival} and Growth. The response of triquetrous murdannia to the tested POST herbicides varied depending on weed growth stage (Table 1). Fluroxypyr and MCPA were able to completely control triquetrous murdannia at any growth stage. None of the triquetrous murdannia plants survived an application of bispyribac-sodium, MCPA + bentazone, or $\mathrm{MCPA}+$ fluroxypyr at the 2- and 4-leaf stage; however, when those herbicides were applied at the 6-leaf stage, the number of surviving plants increased to 10 , 23 , and $15 \%$, respectively. The application of ethoxysulfuron was unable to control triquetrous murdannia at any leaf stage, but it reduced biomass significantly compared with the nontreated control. At the 2-leaf stage, bensulfuron methyl, bentazone, pyrazosulfuron, and pyrazosulfuron + mefenacet had $75,58,75$, and $88 \%$ seedling survival, respectively. These herbicides were unable to control triquetrous murdannia when applied at the 4- and 6-leaf stage, although they significantly reduced shoot biomass.

Manual control of a branching weed such as triquetrous murdannia is very difficult, timeconsuming, and expensive. Therefore, farmers have to rely on herbicides to control triquetrous murdannia. The results of our study suggest that farmers can control this weed through the application of fluroxypyr and MCPA up to the 6-leaf stage in rice fields. Bispyribac-sodium, MCPA + bentazone, or MCPA + fluroxypyr can also be used. However, these herbicides should be applied before the 4-leaf stage to achieve more than $90 \%$ control. In a similar study, bispyribac-sodium, fluroxypyr, and MCPA applied at 45,240 , and $683 \mathrm{~g}$ ai ha ${ }^{-1}$, respectively, were effective to control triquetrous murdannia at the 2- to 3-branch stages in rice fields ( $\mathrm{He}$ et al. 1999; Tian et al. 2015).

In summary, triquetrous murdannia germination was stimulated by light, and more than $80 \%$ of the seeds germinated when incubated at 30/20, 25/15, and $20 / 10 \mathrm{C}$, suggesting that triquetrous murdannia seeds can germinate at low altitudes in subtropical and tropical areas in China. Germination decreased as water stress and salt concentration increased but occurred over a relatively broad range of osmotic potentials and salt concentrations, indicating some degree of tolerance to dry and saline conditions. The highest germination was observed from seeds sown on the soil surface, and emergence was greatly reduced with increases in burial and flooding depths. The use of rice residue as mulch suppressed seedling emergence. The results of our study suggest that adequate tillage and shallow flooding could be effective methods of managing triquetrous murdannia. In the absence of PRE herbicides, the use of POST herbicides such as fluroxypyr and MCPA up to the 5-leaf stage of triquetrous murdannia can provide complete control.

148 • Weed Science 65, January-February 2017 


\section{Acknowledgments}

This work was supported by the Rice Pest Management Research Group of the Agricultural Science and Technology Innovation Program of China Academy of Agricultural Science, China Agriculture Research System (CARS-01-02A). The authors thank all the workers for assistance in conducting this research.

\section{Supplementary material}

To view supplementary material for this article, please visit https://doi.org/10.1614/WS-D-16-00048.1

\section{Literature Cited}

Ahmed S, Opeña JL, Chauhan BS (2015) Seed germination ecology of doveweed (Murdannia nudiflora) and its implication for management in dry-seeded rice. Weed Sci 63:491-501

Ahmed S, Salim M, Chauhan BS (2014) Effect of weed management and seed rate on crop growth under direct dry seeded rice systems in Bangladesh. PLoS ONE 9:e101919

Bao HZ (2003) [Occurrence and integrated management strategies for triquetrous murdannia]. Jiangxi Agric Sci Technol 12:28-29. Chinese

Baskin JM, Baskin CC (1980) Ecophysiology of secondary dormancy in seeds of Ambrosia artemisiifolia. Ecology 61:475-480

Bello IA, Hatterman-Valenti H, Owen MDK (2000) Factors affecting germination and seed production of Eriochloa villosa. Weed Sci 48:749-754

Benvenuti S, Macchia M (1995) Hypoxia effect on buried weed seed germination. Weed Res 35:343-351

Bewley JD, Black M (1994). Seed: Physiology of Development and Germination. 2nd edn. New York: Plenum. Pp 273-282

Bouwmeester HJ, Karssen CM (1993) Seasonal periodicity in germination of seeds of Chenopodium album L. Ann Bot 72: 463-473

Chachalis D, Reddy KN (2000) Factors affecting Campsis radicans seed germination and seedling emergence. Weed Sci 48:212-216

Chauhan BS (2012) Weed ecology and weed management strategies for dry-seeded rice in Asia. Weed Technol 26:1-13

Chauhan BS, Johnson DE (2008a) Seed germination and seedling emergence of giant sensitiveplant (Mimosa invisa). Weed Sci 56:244-248

Chauhan BS, Johnson DE (2008b) Influence of environmental factors on seed germination and seedling emergence of eclipta (Eclipta prostrata) in a tropical environment. Weed Sci 56:383-388

Chauhan BS, Johnson DE (2008c) Germination ecology of goosegrass (Eleusine indica): an important grass weed of rainfed rice. Weed Sci 56:699-706

Chauhan BS, Johnson DE (2009) Influence of tillage systems on weed seedling emergence pattern in rainfed rice. Soil Till Res 106:15-21

Chauhan BS, Johnson DE (2010) The role of seed ecology in improving weed management strategies in the tropics. Adv Agron 105:221-262

Chauhan BS, Johnson DE (2011) Ecological studies on Echinochloa crus-galli and the implications for weed management in direct-seeded rice. Crop Prot 30:1385-1391
Civico RSA, Moody K (1979) The effect of the time and depth of submergence on growth and development of some weed species. Philipp J Weed Sci 6:41-49

Crutchfield DA, Wicks GA, Burnside OC (1985) Effect of winter wheat (Triticum aestivum) straw mulch level on weed control. Weed Sci 34:110-114

Ebrahimi E, Eslami SV (2012) Effect of environmental factors on seed germination and seedling emergence of invasive Ceratocarpus arenarius. Weed Res 52:50-59

Fandrich L, Mallory-Smith CA (2006) Factors affecting germination of jointed goatgrass (Aegilops cylindrica) seed. Weed Sci 54:677-684

Ghorbani R, Seel W, Leifert C (1999) Effects of environmental factors on germination and emergence of Amaranthus retroflexus. Weed Sci 47:505-510

He JH, Sun YJ, Zhou XJ (1999) [Occurrence and chemical control of triquetrous murdannia in rice]. J Zhejiang Agric Sci 5:225-227. Chinese

Koger CH, Reddy KN, Poston DH (2004) Factors affecting seed germination, seedling emergence, and survival of texasweed (Caperonia palustris). Weed Sci 52:989-995

Li Q, Tan JN, Li W, Yuan GH, Du L, Ma S, Wang JX (2015) Effects of environmental factors on seed germination and emergence of Japanese brome (Bromus japonicus). Weed Sci 63:641-646

Li YH (1998) [Weed Flora of China]. 1st edn. Beijing: China Agriculture Press. Pp 1050-1051. Chinese

Liu SW, Zhang YJ, Lin F, Zhang L (2014) Methane and nitrous oxide emissions from direct-seeded and seedling-transplanted rice paddies in southeast China. Plant Soil 374:285-297

Lu M (1991) Occurrence and integrative control of triquetrous murdannia in rice. Weed Sci 2:29-30

Mahajan G, Chauhan BS (2013) Herbicide options for weed control in dry-seeded aromatic rice in India. Weed Technol 27:682-689

Michel BE (1983) Evaluation of the water potentials of solutions of polyethylene glycol 8000 both in the absence and presence of other solutes. Plant Physiol 72:66-70

Nandula VK, Eubank TW, Poston DH, Koger CH, Reddy KN (2006) Factors affecting germination of horseweed (Conyza canadensis). Weed Sci 54:898-902

Opeña JL, Chauhan BS, Baltazar AM (2014) Seed germination ecology of Echinochloa glabrescens and its implication for management in rice (Oryza sativa L.). PLoS ONE 9:e92261

Ramirez AHM, Jhala AJ, Singh M (2012) Germination and emergence characteristics of common beggar's-tick (Bidens alba). Weed Sci 60:374-378

Rao AN, Johnson DE, Sivaprasad B, Ladha JK, Mortimer AM (2007) Weed management in direct-seeded rice. Adv Agron 93: 153-255

Rao N, Dong LY, Li J, Zhang HJ (2008) Influence of environmental factors on seed germination and seedling emergence of American sloughgrass (Beckmannia syzigachne). Weed Sci 56:529-533

Singh S, Singh M (2004) Effect of growth stage on trifloxysulfuron and glyphosate efficacy in twelve weed species of citrus groves. Weed Technol 18:1031-1036

Singh SK, Bharadwaj V, Thakur TC, Pachauri SP, Singh PP, Mishra AK (2009) Influence of crop establishment methods on methane emission from rice fields. Curr Sci 97:84-89

Smith RJJ, Fox WT (1973) Soil water and growth of rice and weeds. Weed Sci 21:61-63 
Stokes CA, MacDonald GE, Adams CR, Langeland KA, Miller DL (2011) Seed biology and ecology of natalgrass (Melinis repens). Weed Sci 59:527-532

Suria ASMJ, Juraimi AS, Rahman MM, Man AB, Selamat A (2011) Efficacy and economics of herbicides in aerobic rice system. Afr J Biotechnol 10:8007-8022

Tan LY (2014) [Pyribenzoxim provides excellent control for triquetrous murdannia in rice fields]. Pestic Market News 19:43-44. Chinese

Teasdale JR, Mohler CL (1993) Light transmittance, soil temperature, and soil moisture under residue of hairy vetch and rye. Agron J 85:673-680

Tian ZH, Shen GH, Lu F, Gu SG, Wen GY (2015) [Study on the occurrence characteristics and chemical control techniques of Murdannia triquetra in wheat and paddy fields]. Acta Agriculturae Shanghai 31:1-5. Chinese
Wang XH, Yu LQ, Li HY, Liao DR, Wang YX, Li MS, Qiu RH (2013) [Biological characteristics, occurrence and distribution of Murdannia triquetra in rice fields of Poyang lake district]. Acta Agriculturae Jiangxi 25:91-93. Chinese

Wei MG, Wang XY, Xie GH (2012) [Field residue of field crops and its temporal distribution among thirty-one provinces of China]. J China Agr Univ 17:32-44. Chinese

Xu ZH, Qi HY, Lu YL, Yang WD, Xie GX (2014). [Weed Identification and Management]. 1st edn. Hangzhou: Zhejiang University Press. 372 p. Chinese

Received March 25, 2016, and approved July 25, 2016.

Associate Editor for this paper: J. Anita Dille, Kansas State University. 